\title{
Distribution Record of Leptophryne borbonica (Tschudi, 1838) (Anura: Bufonidae) from Malang, East Java: Description, Microhabitat, and Possible Threats
}

\author{
Muhamad Prayogi Erfanda ${ }^{1}$, Luhur Septiadi $^{1}$, Sandra Rafika Devi ${ }^{1}$, Berry Fakhry Hanifa ${ }^{2 *}$ \\ 1) Undergraduate Student of Biology Department, Science and Technology Faculty, State Islamic University of Maulana Malik \\ Ibrahim Malang, East Java, Indonesia, 65146 \\ 2) Biology Department, Science and Technology Faculty, State Islamic University of Maulana Malik Ibrahim Malang, East Java, \\ Indonesia, 65146
}

*Corresponding author, tel.: +6282115517089, email address: berryfhanifa@uin-malang.ac.id

\author{
Keywords: \\ distribution records \\ Leptophryne borbonica \\ Hourglass-toad \\ Malang \\ East Java
}

\section{Article history:}

Submitted 24/04/2019

Revised 30/05/2019

Accepted 31/05/2019

\begin{abstract}
Bromo Tengger Semeru National Park (TNBTS) which partly located in Malang, East Java, Indonesia holds various kinds of niches that can support the existence of undiscovered amphibian species. We examine a new distribution of the Leptophryne borbonica, Hourglass-toad from an area located on the slopes of the Southwest of Tengger Mountain as well as its ecological implications related to the possibility of habitat threats. The exploration was carried out on January $1^{\text {st }}$ and March 1 ${ }^{\text {st }}, 2019$, with the description of morphology data and collecting abiotic parameters such as temperature, humidity, altitude, and habitat preference. The distribution of the species was marked. Any important notable records of the habitat threats are documented. The results showed that the amphibians found were Leptophryne borbonica, and set as a new record on Malang, East Java. We suggested that the isolated distribution is very susceptible to ecological disturbances, future ecotourism development, and habitat destruction that prone to local extinction. Further research and conservation efforts need to be carried out for the sustainability of this species in the observation site.
\end{abstract}

\section{INTRODUCTION}

Amphibians diversity data in East Java is still recorded on several localities (van Kampen, 1923) with a lack of further survey afterward. Previous data shows only 39 species of amphibians (mostly dominated by amphibian species of Anura, and 3 species of Gymnophiona) (Iskandar \& Colijn, 2000) in the island of Java, with vast majority data originating from West Java region, especially on the Mount Halimun-Salak National Park and Gunung Gede Pangrango National Park (Iskandar, 1998; Mumpuni, 2001; Kusrini, 2007), and several regions in the Central Java province especially on the Mount Slamet region (Riyanto, 2010). Several attempts to collect amphibian diversity studies have been carried out in East Java, especially in Batu, Malang, Kediri, and other regions (Septiadi et al., 2018b; Hanifa et al., 2016; Indrawati et al., 2018; Hidayah et al., 2018), although more exploration needs to be carried out.
The amphibians diversity data in East Java are very important in assessing its distribution, conservation status and strategies to prevent the threat of declining population.

Malang as the largest regency in East Java has an administrative area of $3,534.86 \mathrm{~km}^{2}$, was surrounded by mountain ranges and a lot of watersheds (Pemkab Malang, 2019). This area has high potency of biodiversity, but still minimal in term of exploration and data of herpetofauna. One area that has high biodiversity potential is Bromo Tengger Semeru National Park (TNBTS) and its surroundings. This region keeps various niches such as high ground, water source, clear water flow, low to high canopy \& dense vegetation, and also plenty of habitat such as arboreal, terrestrial, fossorial, and aquatic type that might support the existence of amphibian species (Septiadi et al, 2018b). This area has a tourism attraction (ecotourism) which 
indirectly impacting on the sustainability of ecosystems, niche and the diversity of species in it.

Leptophryne borbonica (Tschudi, 1838) or Hourglass-toad is a relatively small body toad that has specific hourglass pattern on its back. This species was distributed only in Borneo, Sumatra, Peninsular Malaysia, and also Java Island with type locality from West Java (Iskandar, 1998), and also was recorded in Tengger Mountain, without exact location (Ardiansyah et al., 2014; Iskandar \& Colijn, 2000). Other species found in this genus is Leptophryne cruentata (Tschudi, 1838) which is distributed only in West Java and Central Java (Iskandar and Colijn, 2000; Mumpuni, 2014), and newly recorded species namely Leptophryne javanica Hamidy, Munir, Mumpuni, Rahmania \& Kholik, 2018 which is endemic, protected, and only distributed on the conservation area in the slopes of Mount Slamet and Mount Ciremai in West Java (Hamidy et al., 2018). Distribution mapping, the collection of habitat preference data, the population size of species, and the description related to the possibility of cryptic species in this genus (Hamidy et al., 2018) are very important due to the limited information about this species in East Java. Thus, we report a new distribution with a description of the Hourglass-toad from East Java region as well as its ecological implications related to the possibility of habitat threats to the sustainability of its population.

\section{MATERIALS AND METHODS}

\section{Study Locations}

The specific location (encrypted) is hidden on the Southwest of one of the slopes of the Bromo Tengger Semeru National Park (TNBTS) included in Malang, East Java, Indonesia (Figure 6). The location points are buffer zones that are used as human activities, agroforestry, and nature tourism sites. The small water stream as the habitat of the species L. borbonica, disembogues into a large river bank which is a series of several waterfalls from upstream to downstream and encountered 24 adult and 5 tadpole species of $L$. borbonica. This study carried out on an expedition of "Malang Herpetofauna Biodiversity Project", conducted on January $1^{\text {st }}$ and March 1st 2019.

\section{Specimens Desctiption Data}

Morphological characters were observed as validation of the species description of $L$. borbonica. Eight adult specimens ( 7 adult males, 1 adult female) and 5 tadpoles were deposited on the Ecology Laboratory, Biology Department, State Islamic University of Maulana Malik Ibrahim Malang. Important characters are observed such as patterns and variations on the dorsum side, ventrum side, lateral side of adult specimens which then compared to literature, and also webbing diagrams and formulas (Figure 1) following Glaw and Vences (1994), and tadpole stages determination following Gosner (1960) and McDiarmid \& Altig (1999).

\section{Distribution and Habitat Data}

The survey was conducted using Visual Encounter Survey (VES) method combined with Time Search Sampling method (Hill et al., 2005) starting at 6-12 pm, with only 4-5 person involved. The species distribution mapped out by traversing the water stream as the specific niche of $L$. borbonica, then divided into 3 plots based on stream position (upstream, middlestream and downstream) which disembogues at the bank of a larger river with a length of small watershed approximately $\pm 45 \mathrm{~m}$ ( \pm $15 \mathrm{~m}$ each plot). Observed specimen was marked and the elevation was recorded using Garmin GPSMAP 64s, then the distribution was projected (Figure 2) using QGIS Desktop 2.18.12. The habitat preferences of each individual found in each plot were documented, air temperature and humidity (Table 1) were also recorded using a Thermo hygrometer as a specific habitat reference, and the possibility of predatory species from L. borbonica was also noted along with the observation plot.

\section{RESULTS AND DISCUSSION}

\section{Specimen Description}

Description based on the observation of adult male of Leptophryne borbonica as follows: A small size toad (§ $\mathrm{SVL}= \pm 23.5 \mathrm{~mm}$; + $\mathrm{SVL}=26.10 \mathrm{~mm}$ ), habitus slender, with long forelimbs and a short hindlimbs; bony crest absent, snout projects slightly over the mouth in profile, the tips of finger are rounded (not dilated), firmisternal pectoral girdle present after dissection, paratoid glands indistinct, dorsum with black hour-glass marking, tympanum distinct, a median subgular vocal sac and vocal slit are present on males; skin above wrinkled and scattered on all parts including dorsal surface on the forelimbs and hindlimbs, supratympanic fold absent; Ventrum weakly granulated especially on chest, nuptial pads present on male first finger. Coloration including brown dorsum mottled with black spots on head, back, and limbs; groin and ventral surface of forelimbs and hindlimbs reddish, and webbing are both dorsally and ventrally reddish; belly with suffusion of black and white tend to brownish, chest and throat blackish, limbs with distinct black bars dorsally, upper lip with black bars; pupil horizontal, iris golden with netted black pattern (Figure $1 \& 2$ ). The webbing includes hindlimbs with web formulas 


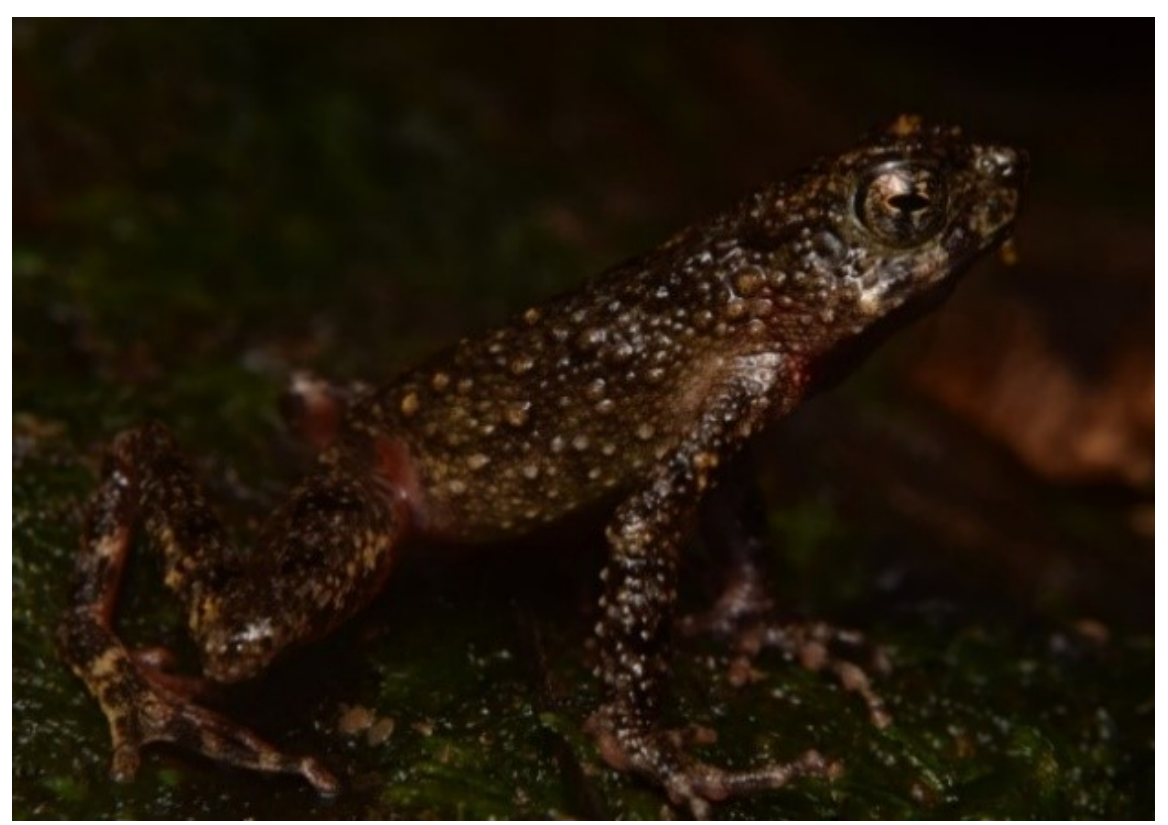

Figure 1. Life photograph of adult male of Leptophryne borbonica from the slopes of the Southwest of Tengger Mountain (Photographed by Luhur Septiadi).

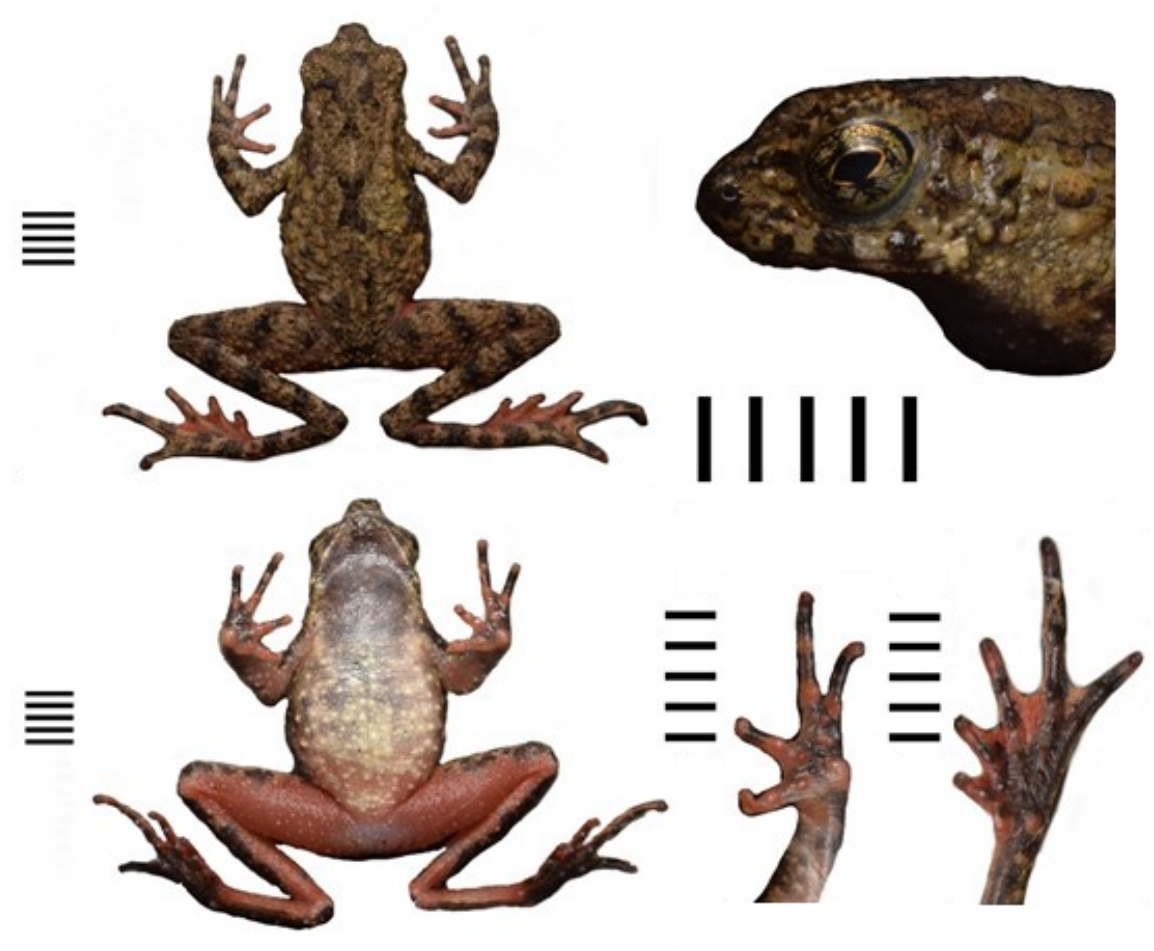

Figure 2. Dorsum and ventrum views (left side), and lateral view of the head, ventral surface of the left hindlimb and left forelimb (right side) of male Leptophryne borbonica from the slopes of the Southwest of Tengger Mountain. Scale bars $=5 \mathrm{~mm}$ (Photographed by Muhamad Prayogi Erfanda).

as follows: I 0-1 II 0-2 III 1-3 IV 23/4-1 V (Figure 4), forelimbs webbings are restricted to the base.

The morphological characters observed are mostly suited to the description of $L$. borbonica (Inger \& Stuebing, 2005; Hamidy et al., 2018) with similar web formulas from Hamidy et. al (2018) (I 1/2-1 II 1 2 III 1/2-3 IV 3-1 V; our direct examination: I 0-1 II 0-2 III 1-3 IV 23/4-1 V), with no black triangular marking behind the eyes, unlike stated by Iskandar with black triangular on some specimens from another localities (Iskandar, 1998)

\section{Microhabitat Preference and Distribution}

A total of 24 specimens of $L$. borbonica were recorded, often found descend on moist rock substrates (97-99\% humidity) on the banks of the slow water stream, damp cliff edges with vegetation of bryophytes mosses (Figure 5), and there none to be found perched on tall leaves or trees (some species perched on low leaves, height approximately 0-1.9 meters from the ground). According to Iskandar (1998), it was found abundant around wet areas or in clear, slowing-moving waters. According 


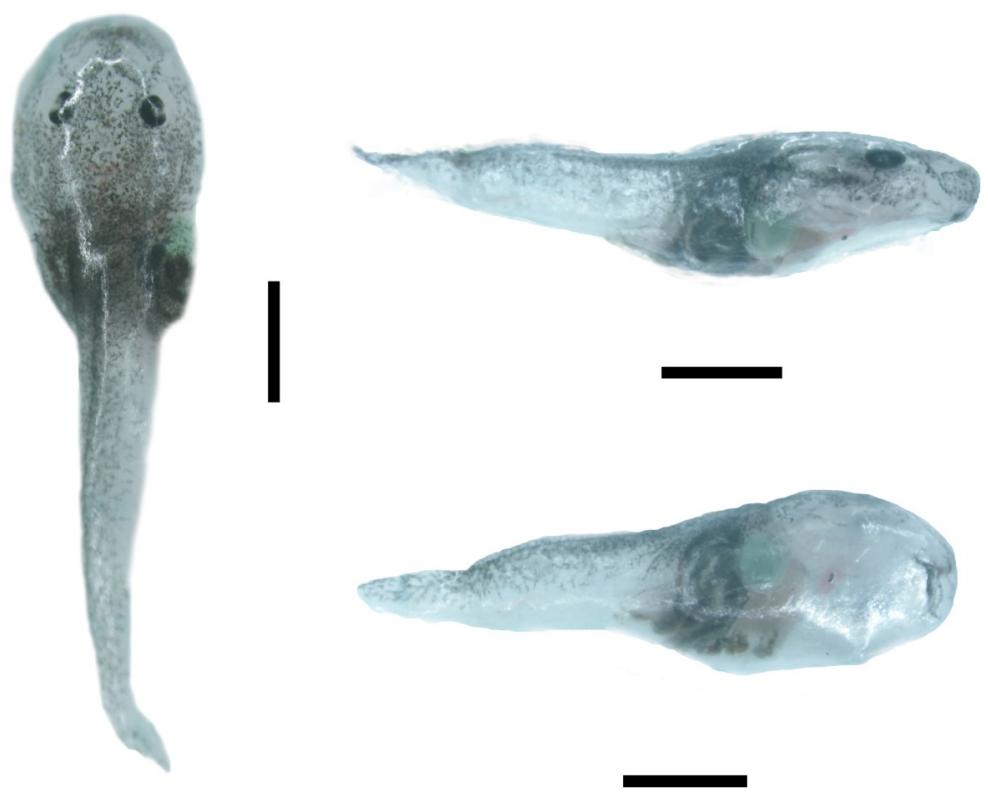

Figure 3. Photos of Leptophryne borbonica preserved specimens of tadpole hatchling. Dorsum views (left side), lateral views (upper right side), ventral views (lower right side) of tadpole at hatchling phase of stage 24th from the slopes of the Southwest of Tengger Mountain. Scale bars $=1 \mathrm{~mm}$ (Photographed by Muhamad Prayogi Erfanda).

to Inger \& Stuebing (2005), this small toad often found in the leaf litters of seepage areas in forests.

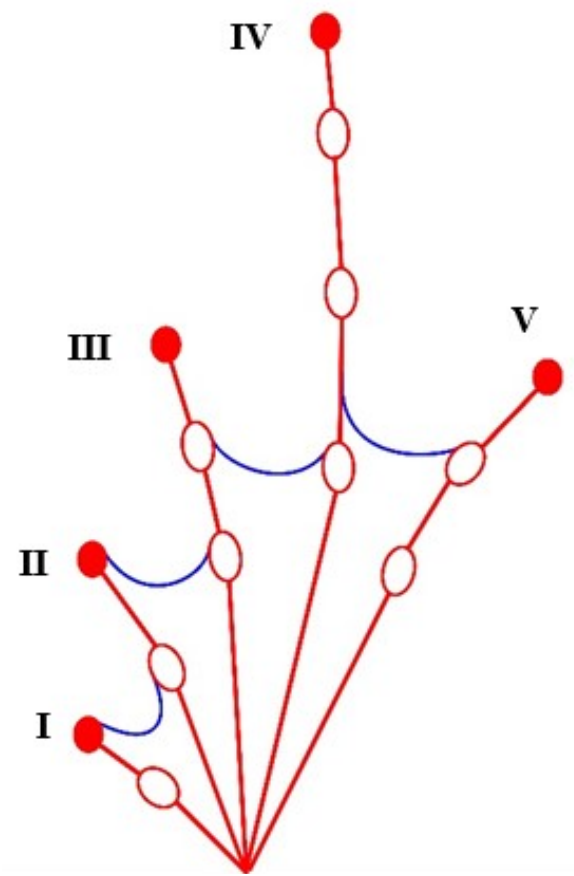

Figure 4. Webbing formula of left hindlimbs of male Leptophryne borbonica, number I - V indicated the inner to outer finger, webbing formulas as follows: I 0-1 II 0-2 III 1-3 IV 23/4-1 V (illustrated by Muhamad Prayogi Erfanda).

Some tadpoles of $L$. borbonica were managed to observe on calm flowing ponds. The tadpoles were obtained at the stage $20^{\text {th }}$ (with no pigmentation, tends to be white translucent, a presence of gill circulation, elongation of tail). Some specimens were taken to the laboratory to clarification and identification purpose. The tadpoles were photographed at the stage $24^{\text {th }}-25^{\text {th }}$ (with development of operculum, oral disc, and pigmentation) (Figure 3) with only one male specimen managed to become adult male. We collected as much as 7, 9, 8 adult individuals respectively encountered in the upstream, middlestream, and downstream, and no species to be found out of the observed plot $(>45 \mathrm{~m})$. The air temperature recorded in the upstream, middlestream, and downstream were $\pm 19^{\circ} \mathrm{C}, \pm$ $20^{\circ} \mathrm{C}, \pm 23^{\circ} \mathrm{C}$ respectively, indicating an increase in air temperature towards the downstream. Humidity recorded at the upstream, middlestream, and downstream were $\pm 97 \%$ ， $498 \%$ ， $499 \%$ respectively, indicating the higher humidity towards the downstream (Table 1). These physical parameters conclude that $L$. borbonica observed to be in varying range of air temperature $19-23^{\circ} \mathrm{C}$ and varying humidity range $97-99 \%$. The species was mostly found in the middlestream of the water flow, and it is difficult to conclude the correlation only by the physical parameters. According to Ardyansah et. al (2014), the abundance of L. borbonica has a weak correlation with physical factors (temperature, humidity, and salinity) at the study location. However, the slightly different in the number of species encounter, indicated that there were other factors that may responsible for this issue. The species abundance indicated to be influenced by the current flow, where this species prefers the calmly 

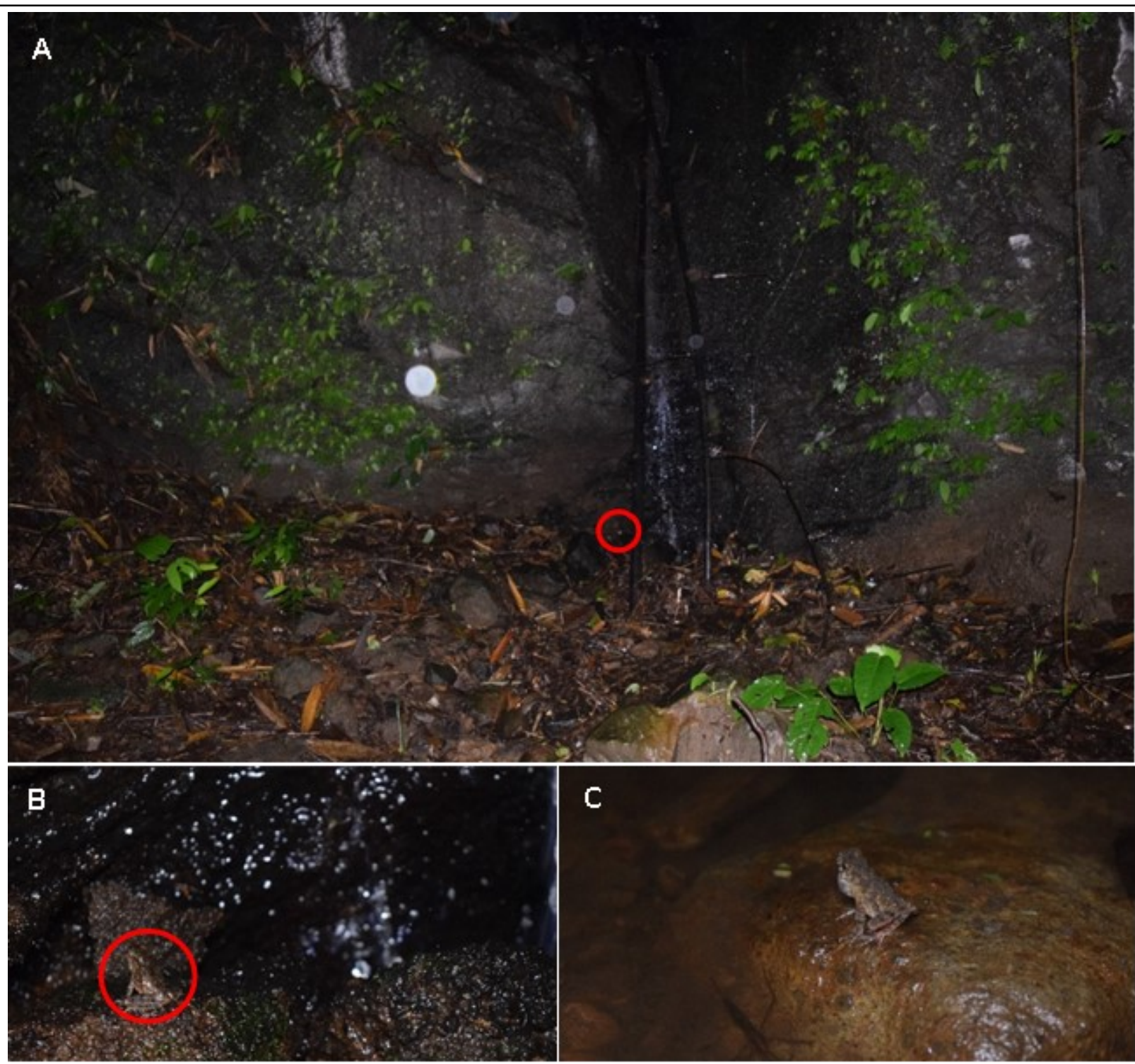

C

Figure 5. The habitat of Leptophryne borbonica from the slopes of the Southwest of Tengger Mountain: (A) upstream habitat, (B) a closer look at L. borbonica on upstream habitat, (C) a species of L. borbonica at downstream habitat; red circle indicated the species-specific location (Photographed by Luhur Septiadi).

flows water for mating purpose, which are mostly found in the middlestream.

Table 1. The physical parameters recorded from each observed plot of L. borbonica niche

\begin{tabular}{llll}
\hline Water stream & $\begin{array}{l}\text { Air } \\
\text { temperature }\end{array}$ & Humidity & Individual \\
\hline Upstream & $\pm 19{ }^{\circ} \mathrm{C}$ & $\pm 97 \%$ & 7 \\
Middlestream & $\pm 20^{\circ} \mathrm{C}$ & $\pm 98 \%$ & 9 \\
Downstream & $\pm 23{ }^{\circ} \mathrm{C}$ & $\pm 99 \%$ & 8 \\
Range & $19-23{ }^{\circ} \mathrm{C}$ & $97-99 \%$ & \pm 8 \\
\hline
\end{tabular}

Distribution mapping shows that the presence of $L$. borbonica is very isolated $( \pm 45 \mathrm{~m}$ ) and currently recorded on a specific location (Malang) especially in East Java. The distribution of L. borbonica can only be found at an elevation of \pm 870-850 m.a.s.l. based on the observed location. According to Hamidy et. al (2018), L. borbonica occurs in both lowlands and highlands up to 1400 m.a.s.l, while according to Inger \& Stuebing (2005), this toad is most often found below 400 m.a.s.l. The presence of L. borbonica is limited by a very steep niche in the upstream area (Figure 5a) and ends with a stream of water that has seeped into the rocks on the downstream area, disembogues into a large river of waterfall stream (Figure 6).

\section{Habitat Threats}

The L. borbonica habitat is threatened by many natural factors, such as predators. Other Anurans species were found, such as Limnonectes microdiscus, Odorrana hossi, and Megophrys montana which might act as natural predators for L. borbonica. Bigger size frogs tend to prey on smaller vertebrate animals (including frogs) in their dietary performing anurophagy. But, the circumstance under which frogs eat another frog are likely to be complex (Measey et al., 2015), further 


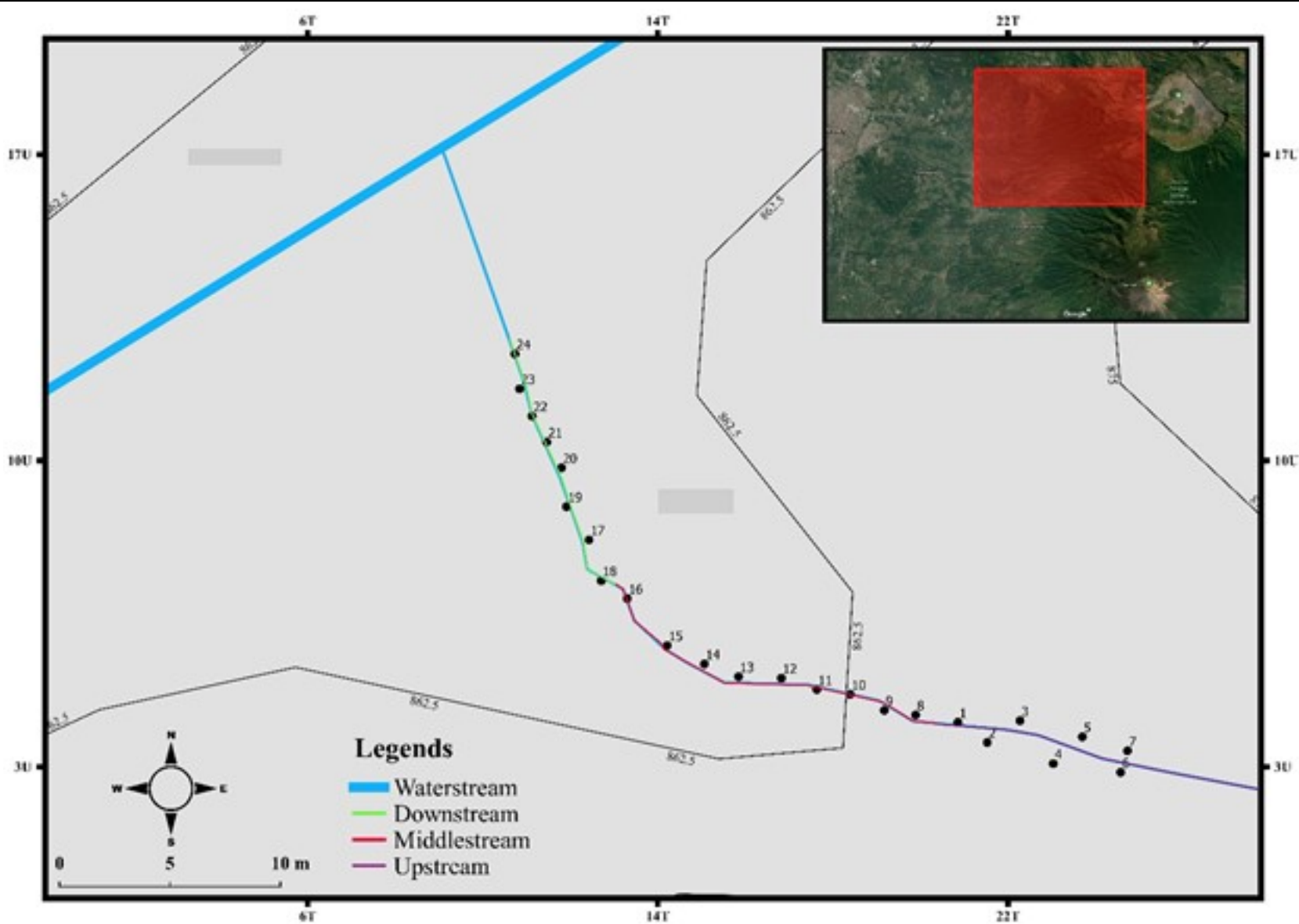

Figure 6. The records location for L. borbonica from the slopes of the Southwest of Tengger Mountain (specific location is encrypted), the number indicated the sequence of specimens encounters, the elevation is indicated by contours, plots is are distinguished by color (projected by QGIS Desktop 2.18.12).

research on dietary (via digestive organ examination) and the interspecific relationship of each species that live in the same niche are yet to be studied. Another habitat threats, include narrow distribution on their specific habitats niche (found only at $\pm 45 \mathrm{~m}$ ) and might be susceptible by the landscape change. Massive landscape changes such as volcanic activities are likely resulting on regional extinctions of this species in East Java. According to IUCN (2014), deforestation is a major threat for this species. Forest clearing for agricultural activities may only have a small impact on the population because they leave the subpopulations to re-invade secondary forest nearly. The species are also threatened by future volcanoes activity of Bromo Tengger Semeru mountain, although this species is widely distributed in Java region (Iskandar, 1998). The nature tourism development will also contribute to habitat loss and disease transmission (Septiadi et al., 2018a), exposing to the infecting chytrid fungus as reported by Kusrini et. al (2008), and a reduction in population size due to the development ecotourism that poorly managed and monitored given its location adjacent to the location of waterfalls. More research and conservation efforts need to be carried out to maintain the existence of the population of $L$. borbonica in the East Java region.

\section{CONCLUSIONS}

New amphibian distribution recorded on the slopes of TNBTS that partly located in Malang, East Java was Leptophryne borbonica (Hourglass-toad) and set as a new record in the East Java region. Its isolated distribution is very susceptible to ecological disturbances, future ecotourism development, infectious disease, population loss, and prone to local extinction. Research data and conservation efforts need to be carried out for the sustainability of the species. Further molecular, morphological and vocalization analysis is also needed to confirm this species of amphibians.

\section{ACKNOWLEDGMENTS}

We would like to thank Anandhika M.S.S., M. Fathoni, M. Zakaria Alwi, and to all ranger of Maliki Herpetology Society Study Club of State Islamic University of Maulana Malik Ibrahim Malang that help this research and provides valuable information and discussion. This research partially supported by IDEA WILD in providing equipment for documenting specimens. 


\section{REFERENCES}

Ardiansyah, D., Karunia, A., Auliandina, T., Putri, D.A., \& Noer, M.I., 2014, Kelimpahan Kodok Jam Pasir Leptophryne borbonica di Sepanjang Aliran Sungai Cisuren, Bodogol, Taman Nasional Gunung Gede Pangrango [The abundance of Hourglass-toad Leptophryne borbonica along the Cisuren River Stream, Bodogol, Mount Gede Pangrango National Park], Bioma, 10(2), 11-18.

Glaw, F., \& Vences, M., 1994, A Fieldguide to the Amphibians and Reptiles of Madagascar. 2nd edition, including mammals and freshwater fish, Vences \& Glaw Verlag GbR Publisher, Frankfurt.

Gosner, K.L., 1960, A simplified table for staging anuran embryos and larvae with notes on identification, Herpetologica, 16(3), 183-190.

Hamidy, A., Munir, M., Mumpuni, M., Rahmania, M. \& Kholik, A.A., 2018, Detection of Cryptic taxa in the genus Leptophryne (Fitzinger, 1843) (Amphibia; Bufonidae) and the description of a new species from Java, Indonesia, Zootaxa, 4450(4), 427-44.

Hanifa, B.F., Ismi, N., Setyobudi, W., \& Utami, B., 2016, Komposisi Amfibi Ordo Anura di Kawasan Wisata Air Terjun Ironggolo Kediri Sebagai Bio Indikator Alami Pencemaran Lingkungan [The Composition of Amphibian from Anura Order in the Ironggolo Kediri Waterfall Tourism Area as a Natural Bio Indicator of Environmental Pollution], Prosiding Seminar Nasional Pendidikan dan Saintek, Jurusan Biologi, Universitas Mubammadiyah Surakarta, 363-368.

Hidayah, A., Hanifa, B.F., Devi, S.R., Septiadi, L., Alwi, M.Z., \& Afifudin, F.A., 2018, Keanekaragaman Herpetofauna di Kawasan Wisata Alam Coban Putri Desa Tlekung Kecamatan Junrejo, Kota Batu, Jawa Timur [Herpetofauna diversity in Coban Putri Nature Tourism Area, Tlekung Village, Junrejo District, Batu City, East Java], Prosiding Seminar Nasional VI Hayati. Universitas Nusantara PGRI Kediri, 79-91.

Hill, D., Fasham, M., Tucker, G., Shewry, M., \& Shaw, P., 2005, Handbook of Biodiversity Methods, Survey, Evaluation and Monitoring, Cambridge Unversity Press, New York.
Indrawati, Y., Hanifa, B.F., Septiadi, L., Alwi, M.Z., Khatimah, A., \& Azizah, I., 2018, Keanekaragaman Jenis Herpetofauna Nokturnal di Area Coban Jahe, Desa Pandansari Lor, Kecamatan Tumpang, Kabupaten Malang, Jawa Timur [Diversity of Nocturnal Herpetofauna in Coban Jahe Area, Pandansari Lor Village, Tumpang District, Malang Regency, East Java], Prosiding Seminar Nasional VI Hayati Universitas Nusantara PGRI Kediri, 277-285.

Inger, R.F., \& Stuebing, R.B., 2005, Panduan Lapangan Katak-katak Borneo [Field Guide of Borneo Frog], Natural History Publications, Kinabalu.

Iskandar, D.T., \& Colijn, E., 2000, Preliminary Checklist of Southeast Asian and New Guinean Herpetofauna: Amphibians I, Research and Development Centre for Biology-LIPI, Bogor.

Iskandar, D.T., 1998, The Amphibians of Java and Bali, Research and Development Centre for Biology-LIPI, Bogor.

IUCN SSC Amphibian Specialist Group, 2014, Leptophryne borbonica, The IUCN Red List of Threatened Species, e.T54814A62029818.

Kusrini, M.D., 2007, Frogs of Gede Pangrango: A follow up project for the conservation of frogs in West Java Indonesia. Book 1: Main report, Institut Pertanian Bogor, Bogor.

Kusrini, M.D., Skerratt, L.F., Garland, S., Berger, L., \& Endarwin, W., 2008, Chytridiomycosis in frogs of Mount Gede Pangrango, Indonesia, Diseases of aquatic organisms, 82(3), 187-194.

McDiarmid, R.W., Altig, R., 1999, Tadpoles: The Biology of Anuran Larvae, University of Chicago Press, Chicago.

Measey, G.J., Vimercati, G., De Villiers, F., Mokhatla, M.M., Davies, S.J., Edwards, S., \& Altwegg, R., 2015, Frog eat frog: Exploring variables influencing Anurophagy, Peerj 3, e1204.

Mumpuni, M., 2001, Keanekaragaman Herpetofauna di Taman Nasional Gunung Halimun, Jawa Barat [Herpetofauna diversity in Gunung Halimun National Park, West Java], Berita Biologi, 5(6), 711-720.

Mumpuni, M., 2014, Keragaman Amfibi dan Catatan Baru Katak di Kawasan Wisata Guci, Provinsi Jawa Tengah [Amphibian Diversity and New Records of Frogs in the Guci Tourist Area, Central Java Province], Zoo Indonesia, 23(1), 13 -19 . 
Pemkab Kabupaten Malang, 2019, 'Selayang Pandang', viewed 27 February 2019, from http://www.malangkab.go.id/site/read/ detail/79/selayang-pandang.html.

Riyanto, A., 2010, Komunitas Herpetofauna dan Potensinya bagi Sektor Ekowisata pada Kawasan Ketenger-Baturraden di Selatan Kaki Gunung Slamet, Jawa Tengah [Herpetofauna Community and its Potential for the Ecotourism Sector in the Ketenger-Baturraden Area in the South of Mount Slamet, Central Java], Majalah Ilmiah Biologi, BIOSFERA: A Scientific Journal, $27(2)$, 60-67.
Septiadi, L., Wahyudi, D., Rachman, R.S., Syafrudin, S., \& Alfaruqi, N.T.S., 2018a, The Invasive Plants Species along the Hiking Track of Mount Panderman Nature Tourism, Batu, East Java, Journal of Indonesian Tourism and Development Studies, 6(1), 55-62.

Septiadi, L., Hanifa, B.F., Khatimah, A., Indawati, Y., Alwi, M.Z., \& Erfanda, M.P., 2018b, Study of Reptile and Amphibian Diversity at Ledok Amprong Poncokusumo, Malang East Java, Biotropika: Journal of Tropical Biology, 6(2), 45-53. van Kampen, P.N., 1923, The Amphibia of the IndoAustralian Archipelago, Creative Media Partners, California. 